\title{
PROSES BERPIKIR LATERAL SISWA SD DALAM MENYELESAIKAN MASALAH MATEMATIKA OPEN-ENDED DITINJAU DARI PERBEDAAN GAYA BELAJAR
}

\author{
Nicky Dwi Puspaningtyas \\ Universitas Teknokrat Indonesia, Jalan Zainal Abidin Pagar Alam, Bandar Lampung \\ nicky@teknokrat.ac.id
}

\begin{abstract}
Abstrak
Berpikir lateral merupakan berpikir diluar kebiasaan dan mencari beberapa alternatif penyelesaian masalah dan diharapkan dapat dikembangkan melalui pembelajaran matematika. Proses berpikir lateral siswa dirasa perlu untuk dideskripsikan agar kita dapat mengetahui sejauh mana siswa mengembangkan kreativitasnya dalam mengembangkan pola pikir matematisnya. Pemberian soal open-ended merupakan salah satu cara yang dapat dilakukan guru dalam mengembangkan kemampuan berpikir lateral siswanya. Hasil dari penelitian ini adalah deskripsi proses berpikir lateral siswa SD dalam menyelesaikan masalah matematika open-ended yang menunjukan bahwa ketiga subjek dengan gaya belajar yang berbeda-beda memiliki proses berpikir lateral. Meskipun demikian, tidak terdapat perbedaan proses berpikir lateral yang signifikan dari ketiga subjek dalam menyelesaikan masalah matematika open-ended.
\end{abstract}

Kata Kunci: proses berpikir lateral, masalah matematika open-ended, gaya belajar.

\begin{abstract}
Lateral thinking is thinking out of the box and looking for several alternatives of solution which are expected can be explored through mathematics learning. The lateral thinking process is important to be described so that we can investigate the students' creativity in explore their mathematical thinking patterns. Open-ended problem can be chosen by teacher to explore students' mathematical thinking. The result of this research is the description of students' lateral thinking in solving mathematical open-ended problem that shows those three subjects with different learning styles have lateral thinking process. Although, there is no significant differences of lateral thinking process in solving mathematical open-ended problem from three subjects.
\end{abstract}

Keywords: lateral thinking process, mathematical open-ended problem, learning styles.

\section{Pendahuluan}

Salah satu tujuan pendidikan nasional berdasarkan Undang-Undang Sistem Pendidikan Nasional Negara Republik Indonesia tahun 2003 adalah untuk mengembangkan kemampuan berpikir kreatif siswa. Kemampuan berpikir kreatif siswa merupakan kemampuan yang perlu digali oleh guru sebab seiring dengan perkembangan jaman, ilmu pengetahuan, teknologi, dan persaingan global, suatu negara dituntut untuk memiliki sumber daya manusia yang inovatif dan memilki kreatifitas yang tinggi.

Untuk mencapai tujuan pendidikan nasional, dibutuhkan suatu proses pembelajaran yang salah satunya adalah pembelajaran matematika. Kemampuan berpikir diluar kebiasaan dan 
mencari beberapa alternatif penyelesaian masalah diharapkan dapat dikembangkan melalui pembelajaran matematika. Kemampuan berpikir yang demikian lebih dikenal dengan kemampuan berpikir lateral.

Berpikir lateral cukup berbeda dengan berpikir vertikal yang mana lebih dikenal sebagai tipe berpikir tradisional. Dengan berpikir vertikal, seseorang dapat mencari berbagai pendekatan berbeda sampai dia menemukan satu pendekatan yang paling menjanjikan sedangkan dengan berpikir lateral seseorang membangun pendekatan sebanyak-banyaknya meskipun dia telah menemukan satu pendekatan yang menjanjikan. Dengan kata lain, dengan berpikir vertikal seseorang mencoba untuk memilih pendekatan terbaik sedangkan dengan berpikir lateral seseorang membangun beberapa pendekatan berbeda dan berusaha untuk membangunnya.

Pemberian soal open-ended merupakan salah satu cara yang dapat dilakukan guru dalam mengembangkan kemampuan berpikir lateral siswanya. Becker dan Shimada (1997) menyatakan bahwa masalah open-ended merupakan sebuah masalah yang memiliki beberapa atau banyak penyelesaian yang benar, dan beberapa cara untuk mendapatkan jawaban yang tepat. Oleh karena itu, dengan memberikan soal open-ended kepada siswa, siswa memiliki kesempatan untuk menyelesaikan permasalahan dalam banyak cara dan mencari banyak alternative penyelesaian. Dengan demikian, berpikir lateral siswa dapat tergali melalui pembelajaran seperti ini.

Faktor lain yang dapat mempengaruhi cara berpikir siswa adalah gaya belajar siswa. Setiap siswa memiliki cara berbeda dalam mempelajari dan memahami informasi. Gunawan (2007:139) menyatakan bahwa siswa yang belajar dengan menggunakan gaya belajar mereka yang dominan, maka saat mengerjakan tes, akan mencapai nilai yang lebih tinggi dibandingkan bila mereka belajar dengan cara yang tidak sejalan dengan gaya belajar mereka. Oleh karena itu, agar tujuan pembelajaran dapat tercapai seperti yang diharapkan, maka dalam proses pembelajaran guru harus menyesuaikan dengan karakteristik cara belajar yang dimiliki masing-masing siswa. Hal ini disebabkan dalam memproses, mendalami dan mempelajari materi pembelajaran setiap siswa memiliki cara yang berbeda-beda.

Berdasarkan latar belakang masalah di atas, rumusan masalah pada penelitian ini adalah: (1) Bagaimanakah proses berpikir lateral siswa sekolah dasar yang memiliki gaya belajar visual dalam menyelesaikan masalah matematika open-ended?; (2) Bagaimanakah proses berpikir lateral siswa sekolah dasar yang memiliki gaya belajar auditori dalam menyelesaikan masalah matematika open-ended?; (3) Bagaimanakah proses berpikir lateral siswa sekolah dasar yang memiliki gaya belajar kinestetik dalam menyelesaikan masalah matematika open-ended? 


\section{Metode Penelitian}

Jenis penelitian ini adalah penelitian eksploratif yang bertujuan untuk mendeskripsikan proses berpikir lateral siswa SD dalam menyelesaikan masalah open-ended ditinjau dari perbedaan gaya belajar siswa. Oleh karena itu, pendekatan yang digunakan dalam penelitian ini adalah deskriptif kualitatif.

Dalam mengumpulkan data, dibutuhkan beberapa instrument pendukung antara lain angket gaya belajar siswa, tugas menyelesaikan masalah, dan pedoman wawancara. Dalam penelitian ini, peneliti menggunakan triangulasi waktu, yaitu mengecek tingkat kepercayaan dan keakuratan data yang diperoleh dengan membandingkan hasil tugas siswa beserta wawancaranya dengan hasil dari tugas yang setara beserta wawancaranya pada waktu yang berbeda. Analisis data dalam penelitian ini mengacu pada tahapan analisis data kualitatif menurut Miles dan Huberman (dalam Sugiyono, 2010) sebagai berikut: reduksi data, pemaparan data, validasi dan penarikan kesimpulan.

\section{Hasil dan Pembahasan}

\section{Proses Berpikir Lateral Subjek dengan Gaya Belajar Visual dalam Menyelesaikan Masalah Matematika Open-ended}

Dalam tahapan mensintesis ide, siswa menggabungkan ide yang didapatkannya dari dua sumber, yaitu ide yang bersumber dari informasi yang telah didapatkan dari pembelajaran di kelas dan berdasarkan pengalamannya dalam menyelesaikan masalah matematika. Siswa memperoleh informasi tentang sifat-sifat segitiga, jumlah sudut segitiga, dan juga jenis-jenis segitiga. Sedangkan melalui pengalaman dalam menyelesaikan masalah matematika, siswa dengan gaya belajar visual menyatakan bahwa ia terbiasa menyelesaikan masalah melalui representasi gambar. Disamping itu, siswa dengan gaya belajar visual menggunakan busur dan penggaris sebagai alat ukur agar mendapatkan gambar yang akurat.

Dalam tahapan membangun ide, siswa dengan gaya belajar visual membangun ide dalam beberapa cara. Hal ini sesuai dengan pendapat Utomo (2001) bahwa berpikir lateral merangsang untuk merubah persepsi, sudut pandang, maupun konsep-konsep yang kita anut demi mengundang munculnya alternatif baru. Pertama, siswa membangun ide dengan menentukan jenis segitiganya terlebih dahulu. Pemilihan jenis segitiga dilakukan berdasarkan sifat-sifat segitiga yang telah didapatkan dalam pembelajaran di kelas. Siswa mengetahui beberapa jenis segitiga, antara lain segitiga siku-siku, lancip, tumpul, sembarang, sama kaki, dan sama sisi. 
Dalam menyelesaikan TMM, siswa dengan gaya belajar visual memilih segitiga siku-siku sebagai jenis segitiga yang pertama, hal ini disebabkan karena siswa merasa mencari ukuran sudut pada segitiga siku-siku lebih mudah dibandingkan dengan jenis segitiga yang lain. Selanjutnya, siswa dengan gaya belajar visual menyelesaikan masalah dengan membuat gambar dengan menentukan ukuran sudut segitiga yang lainnya dengan menggunakan busur. Siswa terkadang kurang teliti dalam mengerjakan sehingga menemukan ukuran sudut yang kurang akurat. Namun saat diminta memeriksa kembali jawabannya, siswa dapat menemukan jawaban yang tepat. Disamping itu, siswa memilih untuk menggunakan bilangan yang mudah untuk dihitung yaitu bilangan bulat. Alasan lainnya adalah karena ukuran sudut dalam bilangan bulat lebih mudah digambar dengan menggunakan busur daripada dalam bilangan desimal.

Dalam tahapan menerapkan ide, siswa dengan gaya belajar visual menerapkan ide yang telah dibangunnya dengan menggunakan persamaan aljabar. Dalam menggunakan persamaan aljabar, siswa menulisnya secara sistematis tahap demi tahap dan mendapatkan jawaban yang benar dan bervariasi. Hal ini bersesuaian dengan pendapat DePorter dan Henarcki (2003) bahwa ciri-ciri individu dengan gaya belajar visual antara lain adalah rapi dan teratur. Serta teliti terhadap detail.

Selanjutnya, siswa menerapkan idenya dengan menggambar segitiga yang hanya salah satu sisinya diketahui. Siswa menentukan ukuran sudut lainnya dan jenis segitiganya. Dalam menerapkan ide ini, siswa sering kurang teliti sehingga ukuran sudut yang diperolehnyapun tidak tepat. Namun saat diminta meneliti kembali jawabannya, siswamenyadari kesalahannya dan mengetahui jawaban yang tepat. Subjek visual ini juga mampu memandang permasalahan dengan sudut pandang yang baru yang mungkin bisa dilakukan dalam menyelesaikan masalah dalam matematika, hal ini sesuai dengan pengertian berpikir lateral menurut Debbi Eposter dan Henacki (dalam Hidayati, 2013: 111) yaitu berpikir lateral adalah melhat permasalahan dari beberapa sudut baru, seolah-olah melompat dari satu tangga ke tangga lainnya.

Secara garis besar, subjek dengan gaya belajar visual dapat dikatakan memiliki proses berpikir lateral karena dalam menyelesaikan masalah, siswa mengamati permasalahan dengan cara yang berbeda, menyusun kembali pola, dan mengembangkan alternatif penyelesaian. Hal ini sesuai dengan tujuan berpikir lateral yang dikemukakan oleh De Bono (1977).

\section{Proses Berpikir Lateral Subjek dengan Gaya Belajar Auditori dalam Menyelesaikan Masalah Matematika Open-ended}

Dalam tahapan mensintesis ide, siswa menggabungkan ide yang didapatkannya dua sumber, yaitu yaitu ide yang bersumber dari informasi yang telah didapatkan dari pembelajaran di kelas 
dan berdasarkan pengalamannya dalam menyelesaikan masalah matematika. Siswa mendapatkan ide dari informasi dan rumus yang telah diajarkan di kelas yaitu mengenai jumlah ukuran sudut pada segitiga $\left(180^{\circ}\right)$ dan jenis-jenis segitiga. Sedangkan melalui pengalaman dalam menyelesaikan masalah matematika, siswa dengan gaya belajar auditori menyatakan bahwa ia akan lebih mudah mengidentifikasi jenis segitiga apabila direpresentasikan melalui gambar.

Dalam tahapan membangun ide, subjek dengan gaya belajar auditori membangun idenya dengan mencoba-coba beberapa bilangan sebagai ukuran segitiga yang ditanyakan terlebih dahulu. Proses pemilihan bilangan dalam cara coba-coba ini didasarkan pada informasi yang telah didapatkan di kelas bahwa jumlah sudut pada segitiga adalah $180^{\circ}$. Selain itu, siswa auditori juga membangun idenya dengan menggunakan representasi gambar. Dalam membangun idenya, siswa hanya menggunakan penggaris sebagai alat bantu ukur. Selanjutnya, siswa dengan gaya belajar auditori membangun ide dengan menentukan jenis segitiga terlebih dahulu. Menurutnya, cara ini memang cukup mudah, namun tidak bisa menghasilkan bermacam-macam jawaban yang tepat. Kemudian, siswa auditori juga memilih untuk menggunakan bilangan yang mudah untuk dihitung dalam menyelesaikan masalah. Menurutnya, pemilihan bilangan desimal memang bisa dilakukan, namun akan sulit saat harus menghitung ukuran sudut yang lain dan apabila harus digambar menggunakan busur. Hal ini juga sesuai dengan pendapat Utomo (2001) bahwa berpikir lateral merangsang untuk merubah persepsi, sudut pandang, maupun konsep-konsep yang kita anut demi mengundang munculnya alternatif baru.

Dalam tahapan menerapkan ide, siswa dengan gaya belajar auditori menerapkan idenya dengan menggunakan cara coba-coba. SA menemukan beberapa jawaban yang benar dengan menggunakan cara coba-coba. Selanjutnya siswa merepresentasikan jawabannya dengan menggunakan gambar. Siswa dengan gaya belajar auditori merepresentasikan jawaban yang didapatkannya melalui cara coba-coba ke dalam gambar sehingga memperoleh bermacam jenis segitiga yang merupakan penyelesaian yang benar dari masalah yang diberikan. Siswa juga menyatakan bahwa masalah TMM dapat diselesaikan dengan menentukan jenis segitiganya terlebih dahulu. Penentuan jenis segitiga berdasarkan informasi yang telah didapatkan di sekolah. siswa dapat mengungkapkan beberapa jawaban benar melalui cara ini. Subjek auditori ini juga mampu memandang permasalahan dengan sudut pandang yang baru yang mungkin bisa dilakukan dalam menyelesaikan masalah dalam matematika, hal ini sesuai dengan pengertian berpikir lateral menurut Debbi Eposter dan Henacki (dalam Hidayati, 2013: 111) yaitu berpikir lateral adalah melihat permasalahan dari beberapa sudut baru, seolah-olah melompat dari satu tangga ke tangga lainnya. 
Dengan demikian, dapat disimpulkan bahwa subjek dengan gaya belajar auditori memiliki proses berpikir lateral karena dalam menyelesaikan masalah, siswa mengamati permasalahan dengan cara yang berbeda, menyusun kembali pola, dan mengembangkan alternatif penyelesaian. Hal ini sesuai dengan tujuan berpikir lateral yang dikemukakan oleh De Bono (1977).

\section{Proses Berpikir Lateral Subjek dengan Gaya Belajar Kinestetik dalam Menyelesaikan Masalah Matematika Open-ended}

Dalam tahapan mensintesis ide, siswa menggabungkan ide yang didapatkannya berdasarkan dua sumber, yaitu yaitu ide yang bersumber dari informasi yang telah didapatkan dari pembelajaran di kelas dan berdasarkan pengalamannya dalam menyelesaikan masalah matematika. Siswa mendapatkan ide dari informasi dan rumus yang telah diajarkan di kelas yaitu mengenai jumlah ukuran sudut pada segitiga, rumus mencari ukuran sudut segitiga, dan jenisjenis segitiga. Sedangkan melalui pengalaman dalam menyelesaikan masalah matematika, siswa dengan gaya belajar kinestetik menyatakan bahwa dengan menggunakan representasi gambar, ia akan lebih mudah menyelesaikan masalah matematika.

Dalam tahapan membangun ide, siswa dengan gaya belajar kinestetik menentukan jenis segitiga terlebih dahulu. Pemilihan jenis segitiga dilakukan berdasarkan informasi yang telah didapatkan dalam pembelajaran di kelas. Dari beberapa jenis segitiga yang telah diketahuinya, siswa memilih segitiga siku-siku untuk dicari ukuran sudut lainnya sebagai pilihan pertama dalam menyelesaikan masalah. Menurut siswa kinestetik, segitiga siku-siku merupakan jenis segitiga yang paling mudah untuk dicari ukuran sudut lainnya. Selain itu, siswa juga membangun ide dengan menggunakan representasi gambar sebagai alternatif jawaban. Siswa mengunakan penggaris sebagai alat bantu menggambar. Disamping itu, siswa dengan gaya belajar kinestetik lebih memilih menggunakan bilangan yang mudah untuk dihitung yaitu bilangan bulat. Hal ini juga sesuai dengan pendapat Utomo (2001) bahwa berpikir lateral merangsang untuk merubah persepsi, sudut pandang, maupun konsep-konsep yang kita anut demi mengundang munculnya alternatif baru.

Dalam tahapan menerapkan ide, siswa dengan gaya belajar kinestetik menerapkan idenya dengan menggunakan persamaan aljabar. Namun persamaan aljabar yang digunakan oleh siswa tidak tersusun secara sistematis. Akan tetapi, dengan menggunakan cara persamaan aljabar, siswa berhasil menemukan jawaban benar yang bervariasi. Juga menggunakan representasi gambar berdasarkan perhitungan yang telah didapatkan dengan menggunakan persamaan 
aljabar. Dengan demikian, siswa juga menemukan bermacam-macam jawaban benar dalam menyelesaikan masalah. Subjek kinestetik ini juga mampu memandang permasalahan dengan sudut pandang yang baru yang mungkin bisa dilakukan dalam menyelesaikan masalah dalam matematika, hal ini sesuai dengan pengertian berpikir lateral menurut Debbi Eposter dan Henacki (dalam Hidayati, 2013: 111) yaitu berpikir lateral adalah melihat permasalahan dari beberapa sudut baru, seolah-olah melompat dari satu tangga ke tangga lainnya.

Berdasarkan tahapan proses berpikir yang dibahas di atas, dapat disimpulkan bahwa subjek dengan gaya belajar kinestetik memiliki proses berpikir lateral. Hal ini dikarenakan dalam menyelesaikan masalah, siswa mengamati permasalahan dengan cara yang berbeda, menyusun kembali pola, dan mengembangkan alternatif penyelesaian. Hal ini sesuai dengan tujuan berpikir lateral yang dikemukakan oleh De Bono (1977).

\section{Simpulan dan Saran}

Berdasarkan hasil pembahasan yang telah diuraikan pada bab sebelumnya, maka dapat ditarik kesimpulan bahwa tidak adanya perbedaan yang berarti antara SV, SA, dan SK dalam proses berpikir lateral. Oleh karena itu, saran dalam penelitian ini adalah guru dalam merancang pembelajaran harus mengembangkan potensi proses berpikir secara luas tanpa membedakan gaya belajarnya. Kajian penelitian ini masih terbatas pada proses berpikir lateral siswa dalam menyelesaikan masalah matematika open-ended ditinjau dari perbedaan gaya belajar visual, auditori, kinestetik. Oleh karena itu, diharapkan penelitian lain yang sejenis agar proses berpikir lateral siswa dapat tereksplor secara optimal.

\section{Referensi}

Becker, J. P. and Shimada, S. 1997. The Open-Ended Approach: A NewProposal ForTeaching Mathematics. Reston, VA: NCTM

De Bono, E. 1977. Lateral Thinking. New York: Pelican Books.

De Porter, B. dan Hernacki, M. 2003. Quantum Learning: Membiasakan Belajar Nyaman dan Menyenangkan. Terjemahan oleh Alwiyah Abdurrahman.Bandung:Kaifa.

Gilakjani dan Ahmadi. 2011. The Effect of Visual, Auditory, and Kinesthetic Learning Styles on Language Teaching. Proceedings of the 2011 International Conference on Social Science and Humanity. International Journal of Modeling and Optimization

Gunawan, A. 2003. Genius Learning Strategy. Jakarta: PT Gramedia Pustaka Utama.

Hidayati, N. N. 2013. Profil Berpikir Lateral Siswa SMK dalam Menyelesaikan Masalah Matematika Kontekstual Ditinjau dari Perbedaan Gender. Tesis. PPs. Unesa Surabaya. 